\title{
REVIEW
}

\section{Basal Cell Carcinoma of the Nipple-Areola Complex: A Comprehensive Review of the World Literature}

Kimberly A. Chun · Philip R. Cohen

Received: May 24, 2016/ Published online: June 30, 2016

(C) The Author(s) 2016. This article is published with open access at Springerlink.com

\section{ABSTRACT}

Background: Basal cell carcinomas (BCCs) usually occur in sun-exposed areas. However, they may also occur-albeit infrequently-in unusual locations, such as the nipple-areola complex.

Methods: Using the PubMed database, an extensive literature search was performed for the following keywords: areola, basal cell carcinoma, and nipple. Papers and references cited in those papers were reviewed to accumulate reports of patients with BCC of the areola and nipple.

Results: BCC of the areola and nipple has been described in 55 individuals: 35 males and 20 females. The onset age ranged from 35 to 86 years. The median onset age in males was 61 years, whereas the median onset age in females was 66 years. BCC of the NAC

Enhanced content To view enhanced content for this article go to http://www.medengine.com/Redeem/ 7ED4F06029C668DD.

\section{K. A. Chun $(\varangle)$ P. P. Cohen}

Department of Dermatology, University of

California San Diego, San Diego, CA, USA

e-mail: kimmchun@gmail.com

P. R. Cohen

e-mail: mitehead@gmail.com predominantly occurred in Caucasians (75.7\%). BCC of the nipple-areola complex (NAC) was observed on the left (54.9\%) more frequently than the right $(45.1 \%)$. Clinical presentation was variable and commonly included scaly or ulcerated plaques and nodules. This tumor was typically associated with the nodular $(42.9 \%)$ or superficial (30.9\%) subtype of BCC. The most common treatment was excision. There were three reported patients who had metastatic disease to their lymph nodes; one of the patients died from his tumor. Conclusion: The nipple and areola are uncommon sites of BCC. BCC of the nipple-areola complex is less frequently observed in females (36.4\%), as this is more commonly a photo-protected site. BCC of the NAC has been considered to behave more aggressively than BCCs at other anatomical sites; however, the BCCs are frequently associated with a non-aggressive histologic subtype. Treatment usually involves complete excision of the BCC. Tumor recurrence was uncommon following successful treatment of the primary neoplasm.

Keywords: Areola; Basal cell carcinoma; Nipple; Review 


\section{INTRODUCTION}

Basal cell carcinoma (BCC) is the most common cutaneous malignancy and accounts for approximately 80 percent of all nonmelanoma skin cancers [1]. Exposure to ultraviolet radiation is the main environmental risk factor associated with the development of BCCs, although they have also been found to occur less frequently in photo-protected sites. Albeit rare, BCCs of the nipple-areola complex (NAC) have been suggested as being more aggressive with higher rates of metastasis to regional lymph nodes [2]. To date, three cases of BCC of the NAC metastatic to the lymph nodes have been described. In comparison, metastatic BCCs from all anatomic sites have been described in a total of 364 cases from 1894 through 2011 [3]. As a result, there has been controversy over the management of BCCs of the NAC.

To address the surveillance and management of BCC of the NAC, an extensive world literature review was conducted to identify cases reported between 1893 and 2016. We review the characteristics of individuals who developed BCCs of the NAC and their management.

\section{METHODS}

Using the PubMed database, a literature search was performed searching for articles related to BCC of the nipple or NAC published in the world literature. The following keywords were used: areola, basal cell carcinoma, and nipple. Relevant papers were reviewed, and the references cited in these papers were evaluated. Information pertaining to age, sex, site of BCC, morphology of BCC, histological subtype of $\mathrm{BCC}$, presence of pigment on histology, previous history of BCC, risk factors, treatment, lymph node involvement, and clinical outcome was identified from each case report. Additional informed consent was obtained from one patient for whom identifying information is included in this article.

\section{RESULTS}

Fifty-five patients with BCC of the nipple and areola have been reported in the world literature, including the patient described in Figs. 1 and 2 (Tables 1, 2) [2, 4-51]. BCC of this site occurred more frequently in males (35, $63.6 \%)$ than in females $(20,36.4 \%)$. The onset age ranged from 35 to 86 years old. The median onset age in males was 61 years, whereas the median onset age in females was 66 years. The onset age was not mentioned for one female [6].

BCCs of the nipple-areola complex were observed on the left $(28 / 51,54.9 \%)$ more frequently than the right $(23 / 51,45.1 \%)$. One patient had bilateral involvement of the areola [37]. Five cases did not report the side affected. The nipple was affected in 45 patients (81.8\%); 22 of these individuals also had tumors that affected the areola.

The majority of patients reported were Caucasian (28/37, 75.7\%). However, BCC of the NAC was also described in 7 Asians (18.9\%), 1 African American (2.7\%), and 1 Hispanic (2.7\%) patient. Ethnicity or race was not described in 18 cases.

Clinical presentation was variable and presented as a plaque $(17 / 34,50 \%)$, nodule $(8 /$ $34,23.5 \%)$, papule $(6 / 34,17.6 \%)$, macule $(2 / 34$, $5.9 \%)$, or patch $(1 / 34,2.9 \%)$. Secondary changes were additionally noted: ulceration or erosion of the BCC was noted in 19 cases, scale in 10, and crust in 7. Clinically, eight BCCs were pigmented. 

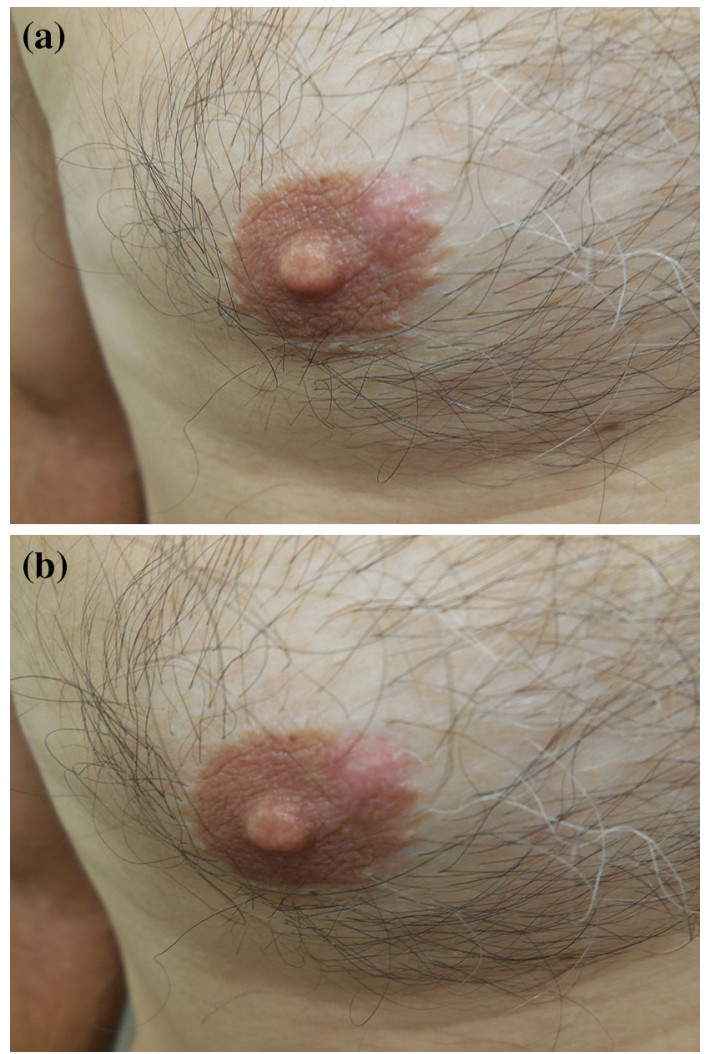

Fig. 1 a, b A previously unreported clinical presentation of basal cell carcinoma of the areola. Distant view (a) of a flesh-colored to hypopigmented dermal nodule on the upper medial quadrant of the right areola in a 67-year-old Caucasian male with Fitzpatrick skin type 2. He had a prior history of basal cell carcinoma on the left arm diagnosed 3 years earlier and presented with a 6-month history of a slowly enlarging, asymptomatic lesion on the right areola and adjacent breast. He had a prior history of moderate sun exposure as a young adult. He had no exposure to ionizing radiation and had no family history of basal cell carcinoma or basal cell nevus syndrome. Closer view (b) of the right breast shows the $7 \times 7-\mathrm{mm}$ flesh-colored to hypopigmented dermal nodule on the upper medial quadrant of his right areola and extending into the adjacent breast. A 3-mm punch biopsy was performed. The patient in these figures is also cited in Table 1 (case 35)

The most frequent BCC histologic type reported was nodular $(18 / 42,42.9 \%)$. Other histologic subtypes of BCC observed were superficial (13/42, 30.9\%), mixed (7/42, $16.7 \%)$, fibroepithelioma of pinkus $(4 / 42$,
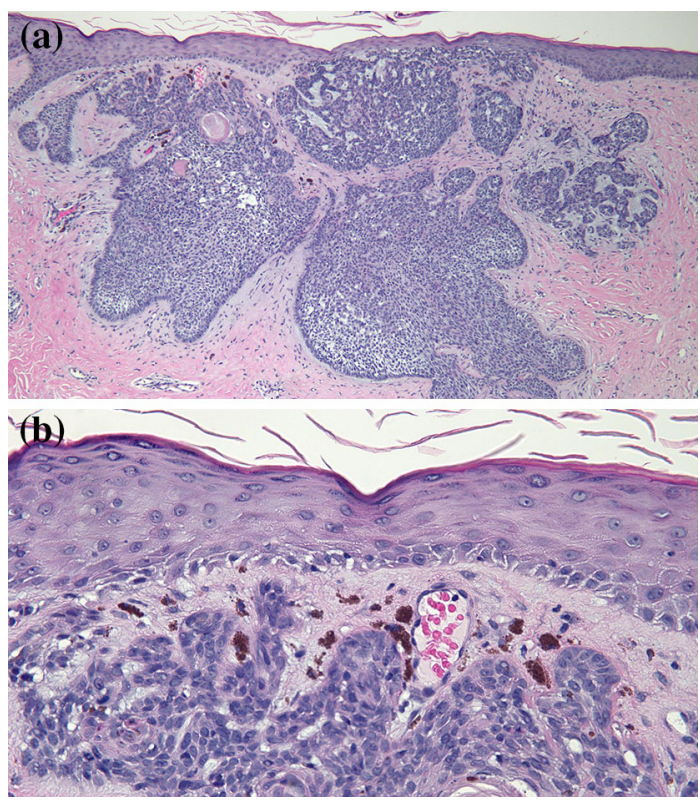

Fig. 2 a, b A previously unreported pathologic presentation of the basal cell carcinoma of the areola shown in Fig. 1. Low (a) and higher (b) magnification views of the pigmented basal cell carcinoma show nodular aggregates of basaloid tumor cells extending from the epidermis into the dermis (a). Deposits of melanin were present not only in the tumor cells but also in dermal melanophages (b). The residual tumor was excised using the Mohs micrographic technique, and clear margins were achieved after three stages. The final wound measured $20 \times 14 \mathrm{~mm}$ and a layered side-to-side closure was used to close the surgical defect. The patient in these figures is also cited in Table 1 (case 35)

$9.5 \%)$, and pigmented $(11 / 42,26.2 \%)$. Of mixed subtypes, four were noted to have aggressive features on histology, including infiltrative $(3 / 7,42.9 \%)$ and micronodular (1/ $7,14.3 \%)$. Thirteen cases did not provide a histological subtype of BCC.

Removal of the tumor was the most common treatment (Tables 1, 2, and 3). This included either simple excision, being the most frequently performed $(15 / 50,30 \%)$, wide excision $(14 / 50,28 \%)$, or Mohs micrographic surgery $(11 / 50,22 \%)$ with examination of the margins during the excision to confirm complete tumor removal. Six patients had 


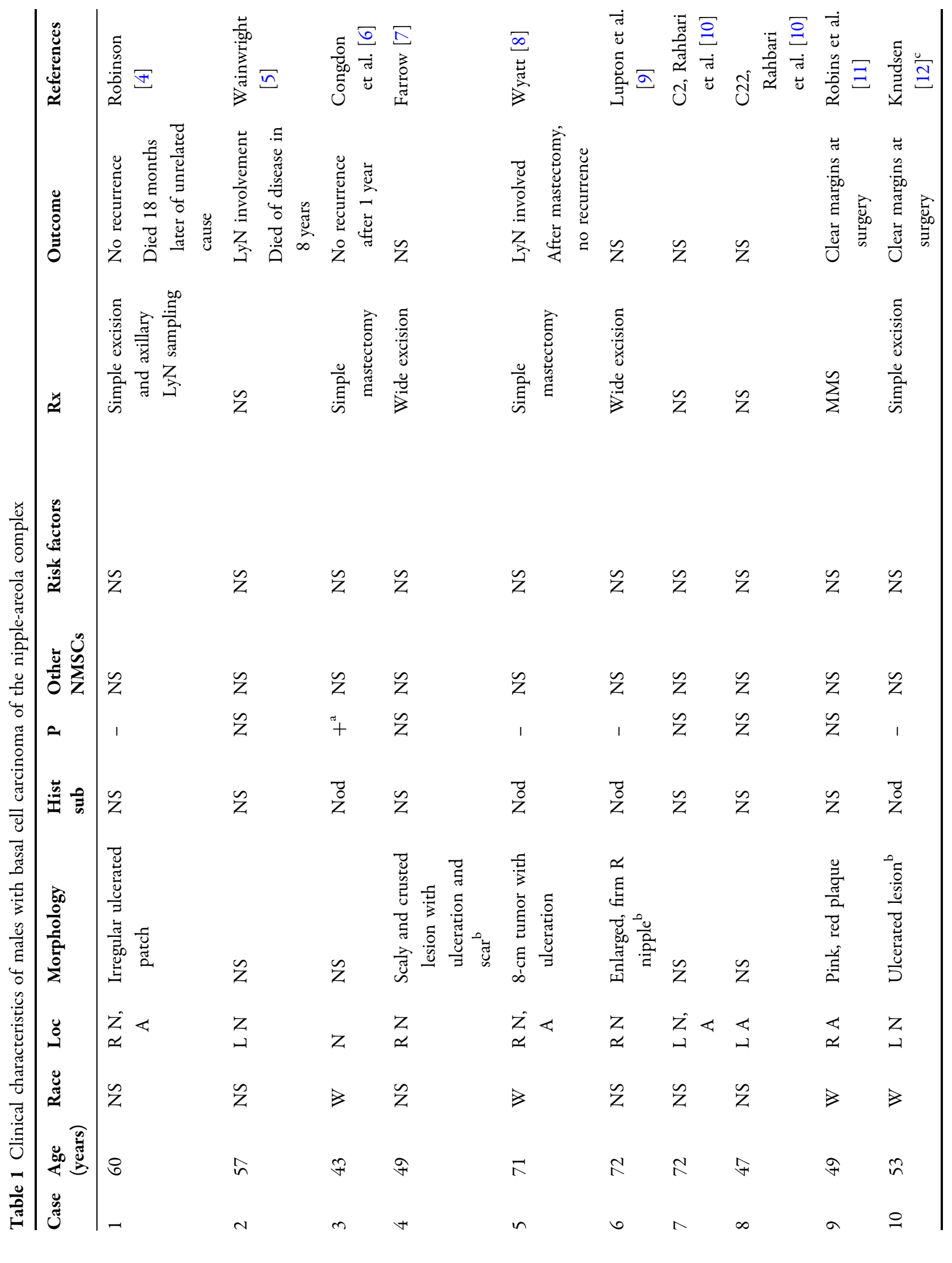




\begin{tabular}{|c|c|c|c|c|c|c|c|c|}
\hline 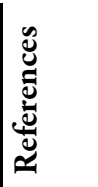 & 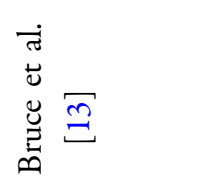 & 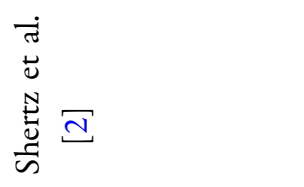 & 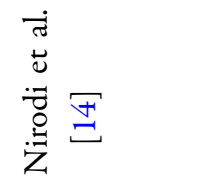 & $\hat{u}$ & 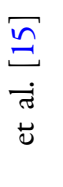 & 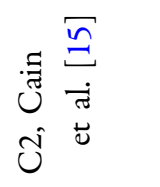 & 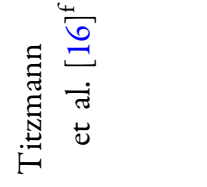 & 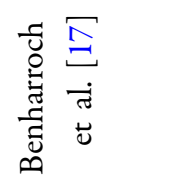 \\
\hline 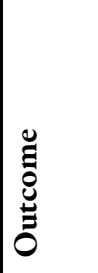 & 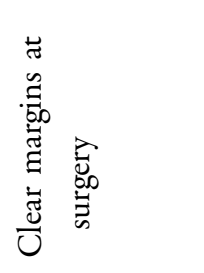 & 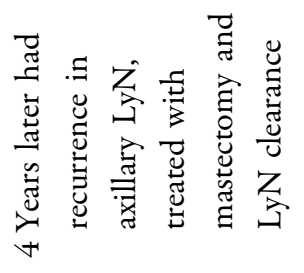 & $\tilde{z}$ & 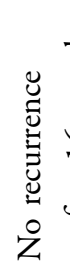 & 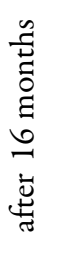 & 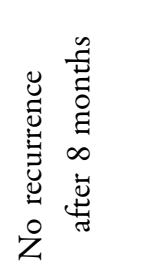 & 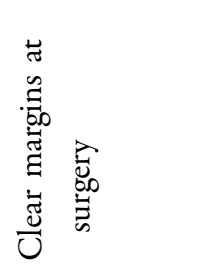 & 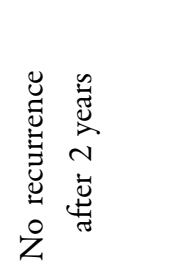 \\
\hline$\approx$ & 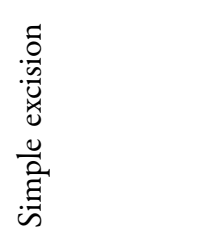 & 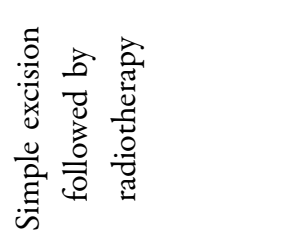 & 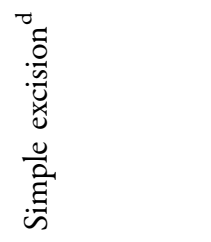 & 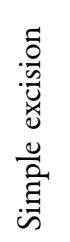 & & 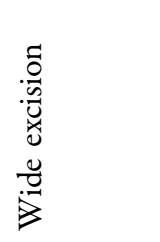 & 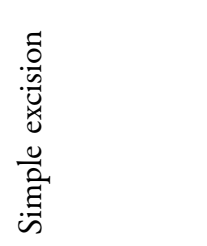 & 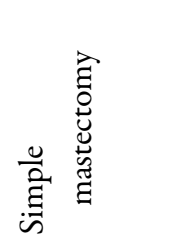 \\
\hline$\frac{0}{0}$ & 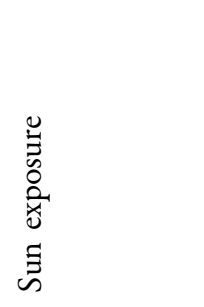 & $\begin{array}{l}\check{\Xi} \\
Z\end{array}$ & 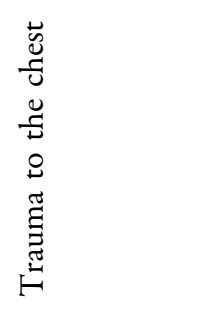 & $\begin{array}{l}\text { Z̃ } \\
\text { Z }\end{array}$ & & $\tilde{z}$ & $\tilde{z}$ & 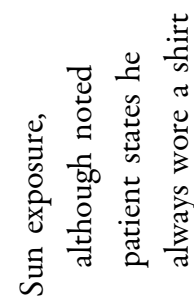 \\
\hline$\frac{\grave{d}}{0} \sum^{n}$ & $\begin{array}{l}\stackrel{0}{0} \\
\text { ż }\end{array}$ & $\begin{array}{l}\text { ̋̃ } \\
\text { Z }\end{array}$ & 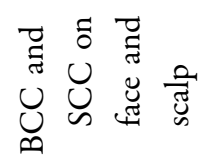 & $\tilde{z}$ & & $\tilde{Z}$ & $\tilde{z}$ & 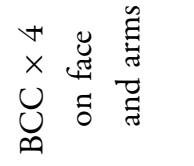 \\
\hline$a$ & 1 & 1 & 1 & 1 & & 1 & + & 1 \\
\hline 䓂完 & $n$ & $\ddot{\Sigma}^{\vec{z}}$ & 山 & zo & & 山 & $\stackrel{2}{\xi}$ & $\begin{array}{l}\overline{0} \\
\dot{z}\end{array}$ \\
\hline 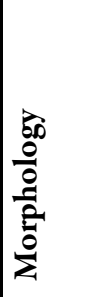 & 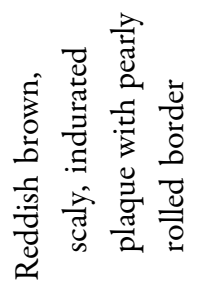 & 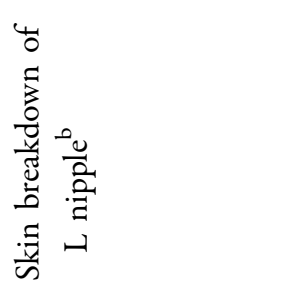 & 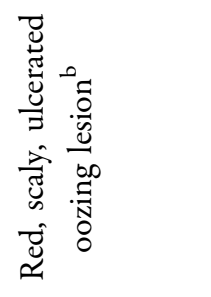 & 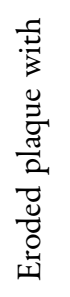 & 容 & 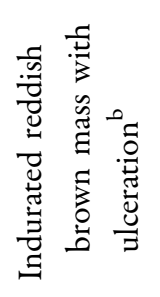 & 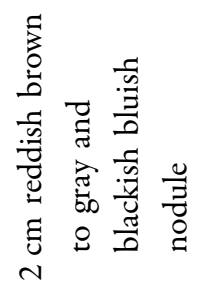 & 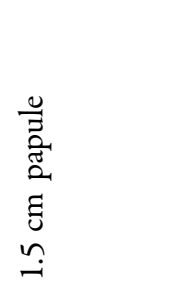 \\
\hline 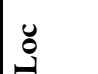 & $\dot{z} \varangle$ & z & Z & Zz & $\varangle$ & $\underset{z}{2} \ll$ & z & Z \\
\hline שֶّ & $\geqslant$ & $\tilde{z}$ & $\tilde{z}$ & $\geqslant$ & & $\geqslant$ & $\geqslant$ & $\geqslant$ \\
\hline 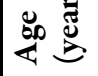 & $\bar{n}$ & $\stackrel{\infty}{n}$ & $\bowtie$ & $\widetilde{\sigma}$ & & ஓ & $\approx$ & $\hat{n}$ \\
\hline Uू & $=$ & $\simeq$ & 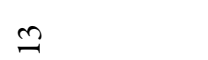 & $\Xi$ & & $\simeq$ & $\stackrel{\ddots}{-}$ & I \\
\hline
\end{tabular}




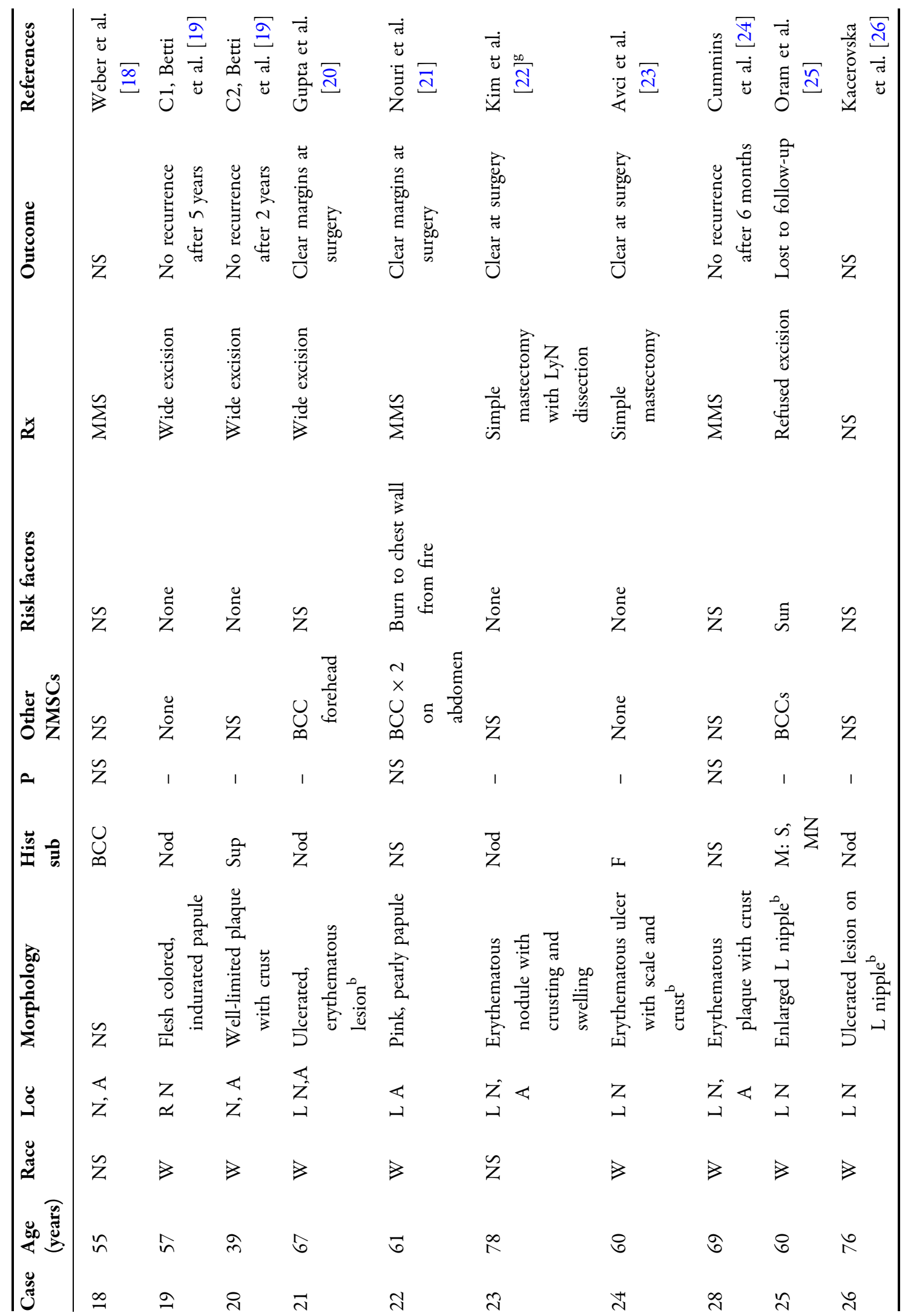




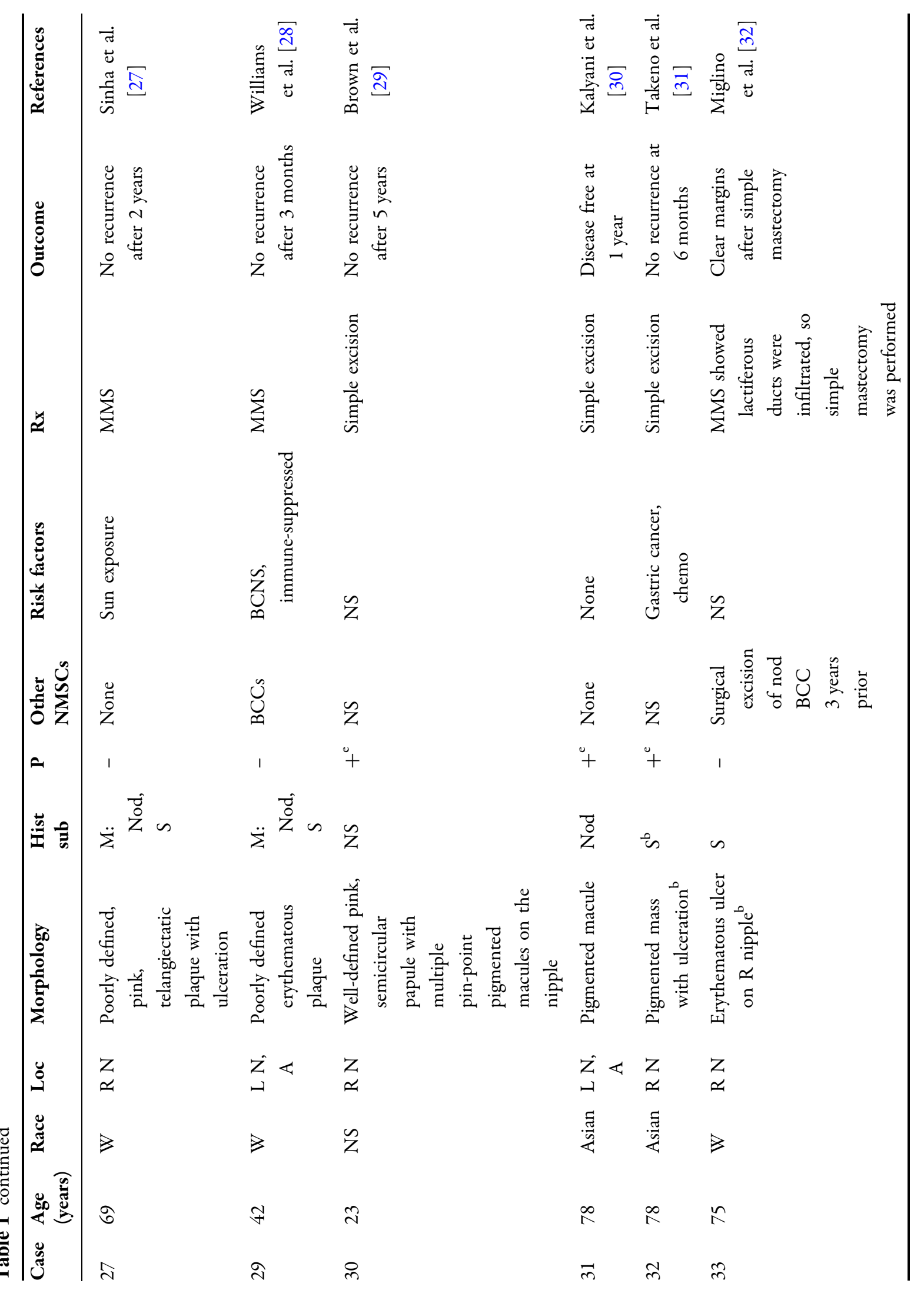




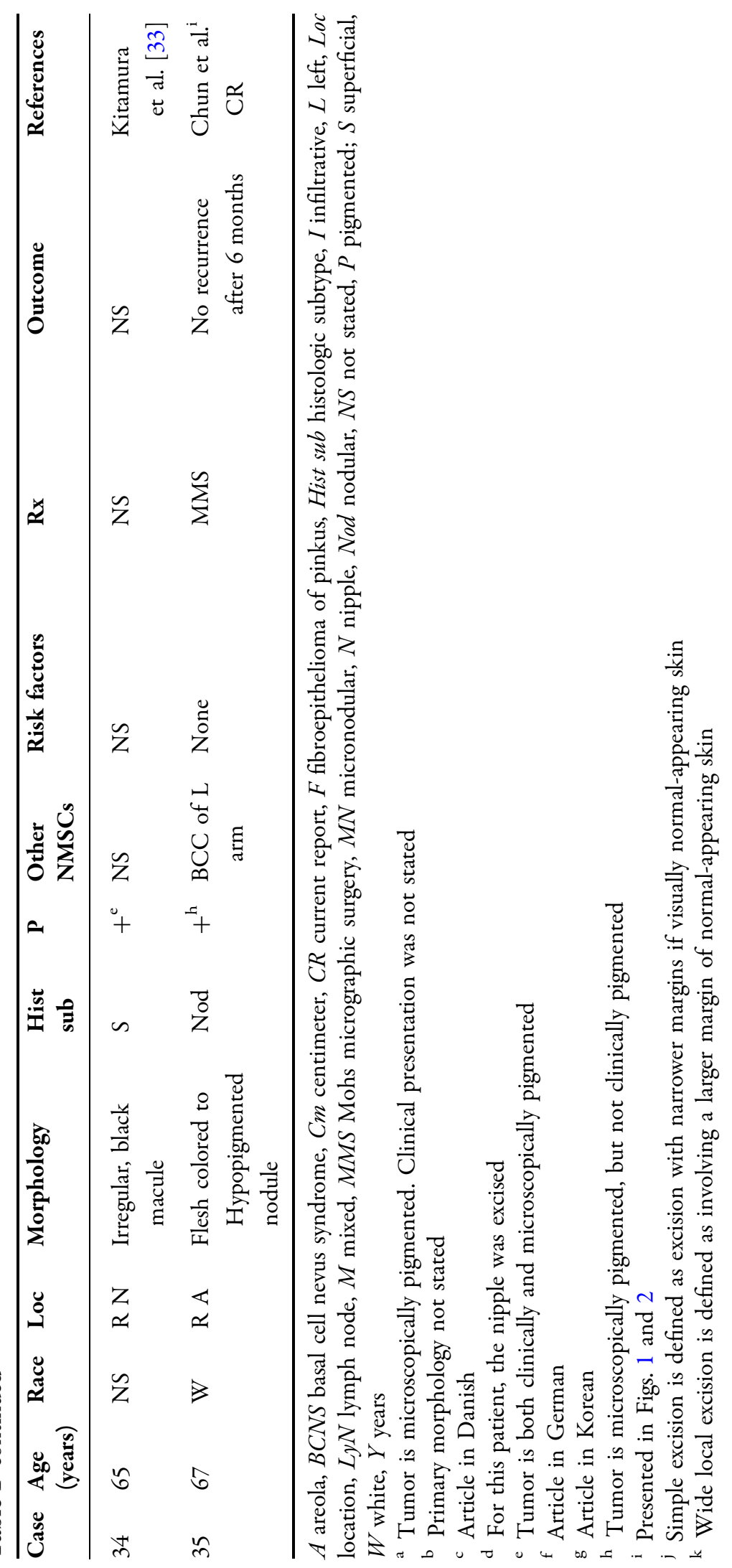




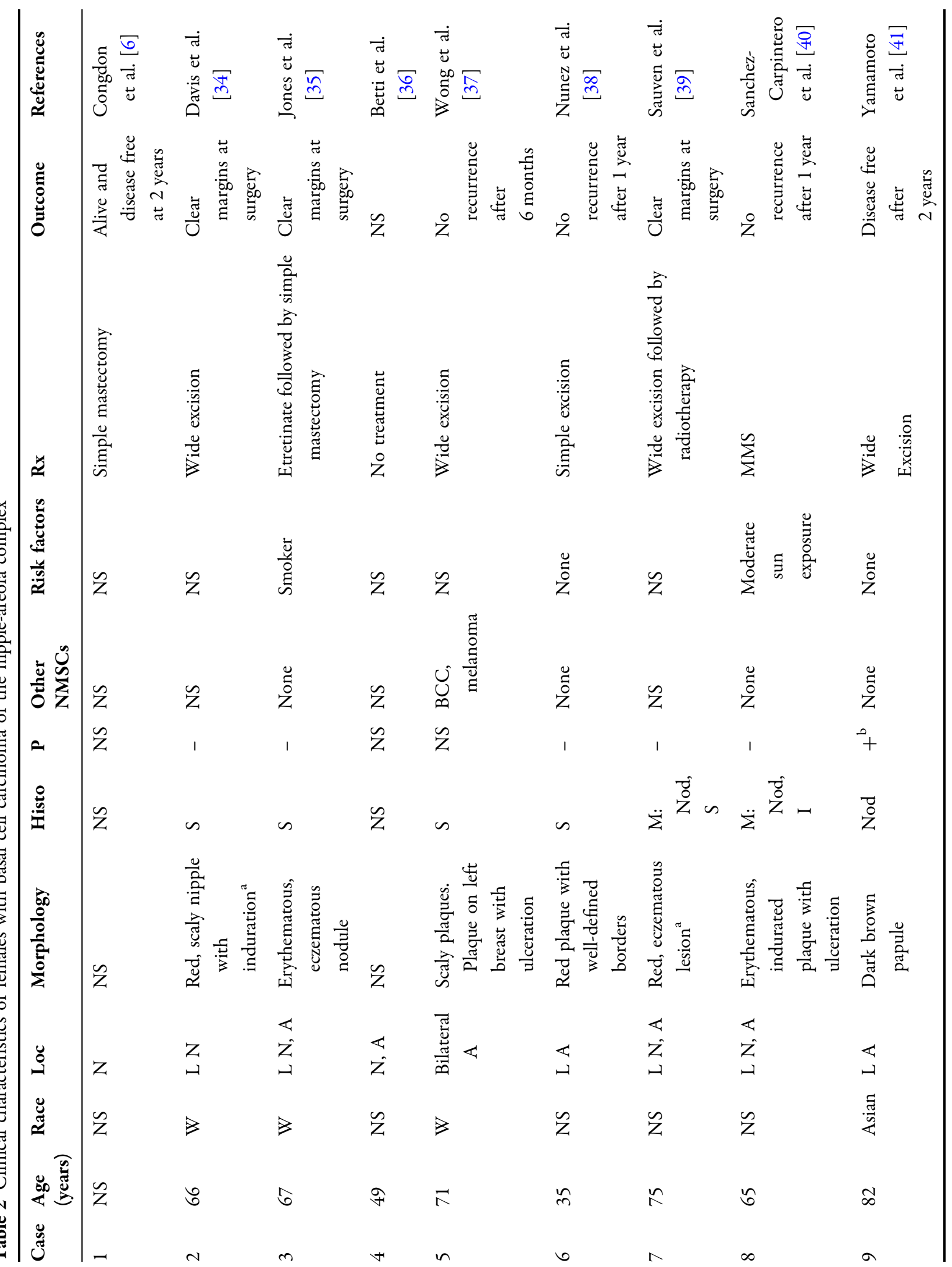




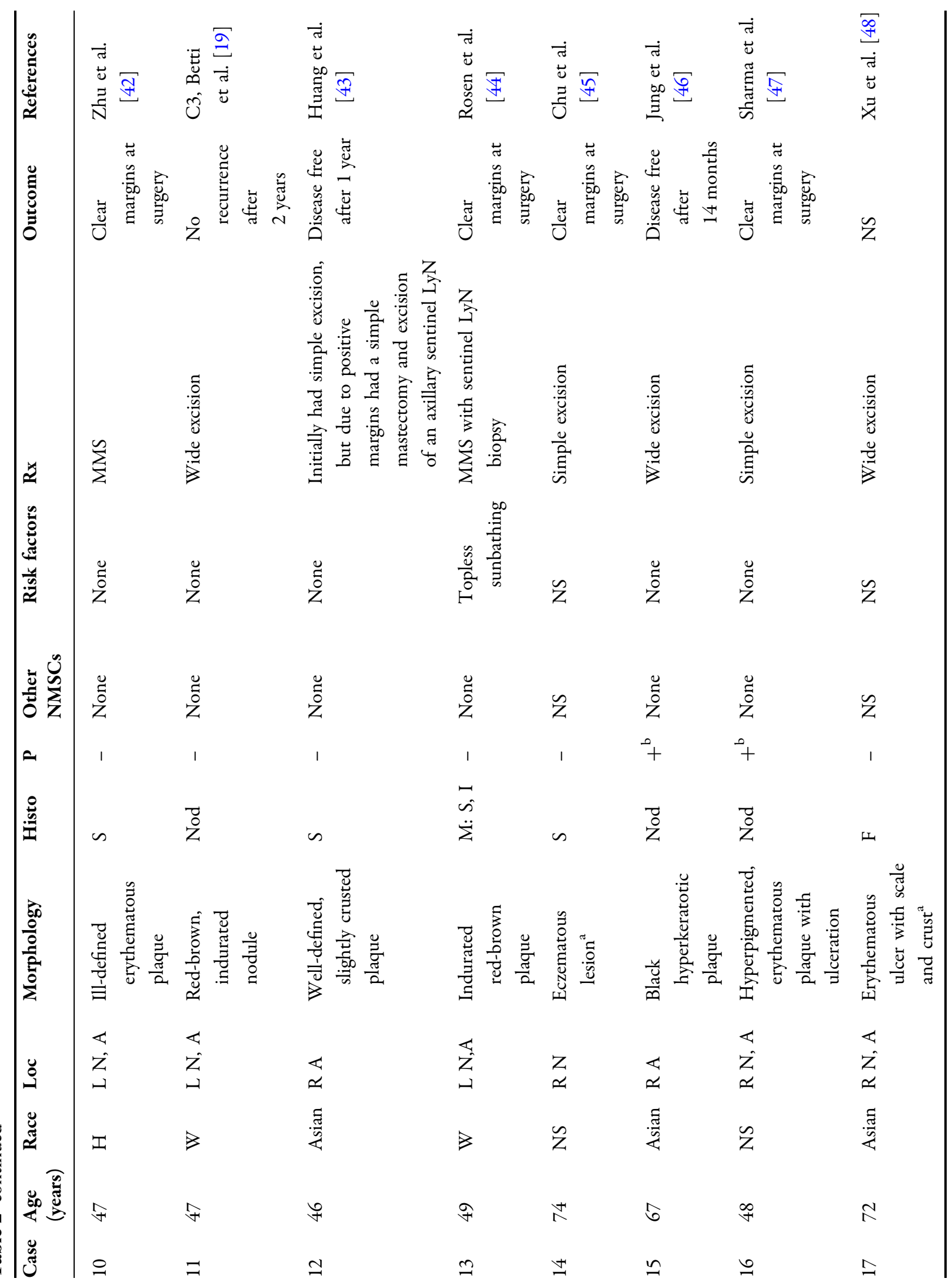




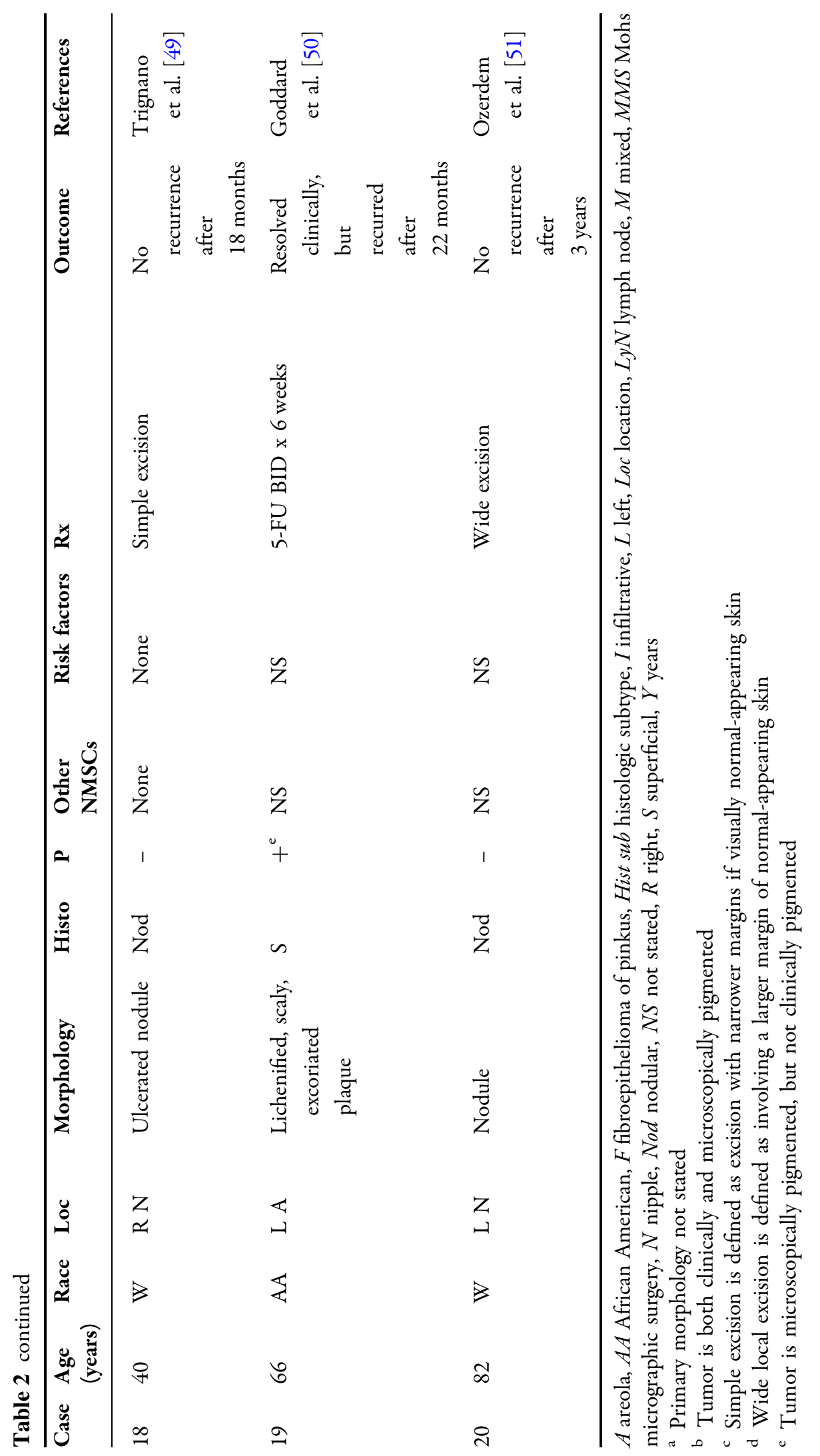


Table 3 Initial treatment of basal cell carcinomas of the nipple-areola complex

\begin{tabular}{llll}
\hline Initial treatment $^{\mathbf{a}}$ & Males $^{\mathbf{b}}$ & Femalesn $^{\mathbf{c}}$ & Total $^{\mathbf{d}}$ \\
\hline Simple excision & $10^{\mathrm{e}}$ & $5^{\mathrm{f}}$ & 15 \\
Wide excision & 6 & $8^{\mathrm{g}}$ & 14 \\
MMS & $8^{\mathrm{h}}$ & 3 & 11 \\
Simple mastectomy & 5 & $1^{\mathrm{i}}$ & $6^{\mathrm{j}}$ \\
5-Fluorouracil & 0 & $1^{\mathrm{k}}$ & 1 \\
Etretinate & 0 & $1^{1}$ & 1 \\
No treatment & 1 & 1 & 2 \\
Total & 30 & 20 & 50 \\
\hline
\end{tabular}

MMS Mohs micrographic surgery

a Initial treatment not stated in 5 males

b Number of males for whom treatment was performed

c Number of females for whom treatment was performed

d Total number of males and females for whom treatment was performed

e This group includes one patient whose nipple was excised, and the excision type was not specified. Two patients had subsequent treatment including either axillary lymph node sampling or radiotherapy

${ }^{f}$ One female had additional treatment: simple mastectomy and lymph node sampling

g One female had additional treatment: radiotherapy

h Following MMS, one male had a simple mastectomy

i One female was treated with etretinate and subsequently had a simple mastectomy

j Simple mastectomy was the initial treatment for six patients; however, nine mastectomies were eventually performed. One male was initially treated with MMS, and one female initially treated by simple excision followed by radiotherapy; one female was initially treated with etretinate

k One female was treated with 5-fluorouracil twice daily for 6 weeks. The BCC initially resolved, but recurred at 22 months

${ }^{1}$ Following etretinate therapy, one female had a simple mastectomy

simple mastectomies as their initial modality of treatment $(6 / 50,12 \%)$.

One patient received topical 5-flourouracil (5-FU) twice daily for 6 weeks [50]. One female was treated with etretinate followed by simple mastectomy [35]. In addition, two patients received no treatment $[25,36]$. In five males, there was no mention of management.

One male had Mohs micrographic surgery, which showed the lactiferous ducts had been infiltrated; thus, a simple mastectomy was performed (2\%) [32]. One male had a simple excision followed by radiotherapy, but 4 years later was noted to have recurrence in the axillary lymph node and thus had a simple mastectomy (2\%) [2]. One female had a simple excision, but due to positive margins, she subsequently had a partial mastectomy (2\%) [43].

Most of the patients $(43 / 45,95.6 \%)$ had no recurrence after successful treatment of their tumor. In ten patients, there was no mention of clinical outcome. There had been three reported cases of metastatic disease to the lymph nodes at the time of this review, and of these patients, one died from the disease.

\section{DISCUSSION}

BCCs infrequently occur at unusual sites, such as the nipple and areola. Previous studies have 
noted a close histogenic relationship between BCCs and pilosebaceous units [52-54], and BCCs are therefore thought to arise in proportion to the number of pilosebaceous units present [25]. The nipple and areola are deficient in these units, which may explain the paucity of BCCs of the nipple and areola.

After an extensive world literature search, we identified 55 cases of BCC of the NAC from 1893 to 2016 (123 years). A 2009 review by Ferguson et al. revealed 33 cases of BCC of the nipple and areola [55]. Since 2009, 22 additional cases of BCC of the NAC have been reported in the world literature. This apparent increase in BCCs of this site may be due to a publication bias; however, this trend reflects an overall increased incidence of sporadic BCCs [56].

The increased incidence of BCC of the NAC observed in males $(35,63.6 \%)$ versus females $(20$, $36.4 \%)[2,4-51]$ has been attributed to greater sun exposure of the chest in males $[2,13,15,20,27,41,42]$. Although ultraviolent light exposure is the major risk factor for the development of BCC, other etiologies include arsenic exposure, genetic predisposition, environmental exposures, immunosuppression, ionizing radiation exposure, injury (burns or trauma), light-colored skin, previous BCCs at another site, and sunburns. Although the majority of cases did not reveal possible risk factors of BCC of the NAC, our review revealed two males (Table 1, cases 11 and 26) [13, 27] and two females (Table 2, cases 8 and 13) $[40,44]$ had increased sun exposure to the chest from shirtless sunbathing. Nine patients $(9 / 26,34.6 \%)$ had a prior history of BCC $[14,17,20,21,25,28,32]$. Two males reported prior trauma to the chest (2/ $27,7.4 \%)[14,21]$. One male had basal cell nevus syndrome $(1 / 27,3.7 \%)$ [28], and one male was immunosuppressed on chemotherapy for gastric cancer $(1 / 27,3.7 \%)$ [31].
To date, there have been eight patients with clinically pigmented BCCs of the NAC. Therefore, primary melanoma of the NAC, pigmented Paget disease, and pigmented epidermotropic metastases are important considerations in the clinical differential diagnosis of a pigmented lesion of the NAC. These can be differentiated by histologic examination and immunohistochemistry markers, such as CEA, cytokeratins, EMA, HMB-45, MART1, microphthalmia transcription factor (MiTF), and S-100 [29, 57].

Interestingly, two patients (including the patient described in Figs. 1 and 2) with histologic findings of pigmented BCC had flesh-colored non-pigmented clinical lesions [50]. The clinical presentation of one male with microscopic pigmented BCC was not described [6].

Confirmation of BCC of the NAC requires a biopsy, although other approaches are available to evaluate a suspected diagnosis of BCC, including confocal laser scanning microscopy and dermoscopy.

Confocal laser scanning microscopy, also known as reflective confocal microscopy, is a noninvasive diagnostic method that enables real-time imaging of the skin layers and cellular structures in the horizontal plane [58]. Classical findings of BCC on confocal laser scanning microscopy include five confocal imaging criteria: presence of elongated monomorphic basaloid nuclei, polarization of these nuclei along the same axis of orientation, heavy inflammatory infiltrate, increased vasculature, and pleomorphism of the overlying epidermis indicating actinic damage [59].

Dermoscopy is another noninvasive method that allows for the in vivo evaluation of structures and colors of the epidermis, dermoepidermal junction, and papillary 
dermis not visible to the unaided eye. Dermoscopic diagnosis of BCC involves the absence of a pigmented network and presence of at least one of the following classical criteria: multiple blue-gray globules, large blue-gray ovoid nests, maple leaf-like areas, spoke-wheel areas, arborizing telangiectasia, and ulceration [60]. Non-classical dermoscopic criteria are also helpful for the diagnosis of BCCs, especially early lesions, and include short fine superficial telangiectasia, concentric structures, multiple small erosions, multiple in-focus blue-gray dots, blue whitish veil, shiny pink-white areas, and milia-like cysts [61].

Due to the infrequent presentation of BCC of the NAC, there has been a lack of characteristic findings in the literature to aid in the diagnosis of BCC of the NAC. However, a recent review by Kitamura et al. revealed a dermoscopic feature of pigmented BCC of the NAC that was termed a 'large black web.' On dermoscopic evaluation, it was noted that the black network structure was thicker than the typical pigment network of the areola, and the surrounding area consisted of arborizing vessels and spoke-wheel areas. When this patient was compared with nine others diagnosed with superficial BCC of the trunk, the authors found that the 'large black web' was unique to BCC of the NAC and appeared to avoid the hair follicles [33].

Earlier investigations have reported an increased metastatic potential of BCC of the nipple and areola. These studies hypothesized that the increased lymphatics of the NAC may provide a direct route for tumor spread. There have been three cases of BCC of the NAC with lymph node involvement (Table 1 , cases 2,5 , and 12) $[2,5,8]$, which is a minimum metastatic rate of $5.5 \%$. Since the outcome was not stated in ten patients and several patients had a short duration of follow-up after surgery, this rate could potentially be higher.
The histologic subtypes observed were most commonly nodular (42.9\%) and superficial (30.9\%); less often they showed pigment microscopically $(11 / 42, \quad 26.2 \%)$, mixed histology $(16.7 \%)$, or fibroepithioloma of Pinkus variant $(9.5 \%)$. Of the mixed subtypes, four cases were noted to have features associated with aggressive subtypes, such as infiltrative $(3 / 7,42.9 \%)$ and micronodular (1/ 7, 14.3\%) BCCs.

Given the concern for higher metastatic potential or the presence of positive excision margins for tumors, nine patients underwent a simple mastectomy, although tissue-sparing surgery, such as simple excision, wide local excision, and Mohs micrographic surgery, was most commonly utilized. Recurrence of NAC BCC is low and was noted in one male who demonstrated lymph node involvement that occurred 4 years after simple excision [2].

\section{CONCLUSION}

BCC of the NAC has been reported in 55 individuals. More males were affected than females; the left side was affected more than the right. Most commonly, these tumors presented as plaques with ulceration. The most frequent histologic subtype of BCC of NAC was nodular BCC. Although previous reports raise the concern of metastatic potential, most patients have been successfully treated with excision of the tumor.

\section{ACKNOWLEDGMENTS}

No funding or sponsorship was received for this study or publication of this article. All named authors meet the International Committee of Medical Journal Editors (ICMJE) criteria for authorship for this manuscript, take 
responsibility for the integrity of the work as a whole, and have given final approval for the version to be published.

Disclosures. Kimberly A. Chun and Philip R. Cohen have nothing to disclose.

Compliance

with

Ethics

Guidelines. Additional informed consent was obtained from one patient for whom identifying information is included in this article.

Open Access. This article is distributed under the terms of the Creative Commons Attribution-NonCommercial 4.0 International License (http://creativecommons.org/licenses/ by-nc/4.0/), which permits any noncommercial use, distribution, and reproduction in any medium, provided you give appropriate credit to the original author(s) and the source, provide a link to the Creative Commons license, and indicate if changes were made.

\section{REFERENCES}

1. Rubin AI, Chen EH, Ratner D. Basal-cell carcinoma. N Engl J Med. 2005;353(21):2262-9.

2. Shertz WT, Balogh K. Metastasizing basal cell carcinoma of the nipple. Arch Pathol Lab Med. 1986;110(8):761-2.

3. Wysong A, Aasi SZ, Tang JY. Update on metastatic basal cell carcinoma: a summary of published cases from 1981 through 2011. JAMA Dermatol. 2013;149(5):615-6.

4. Robinson HB. Rodent ulcer of the male breast. Transact Pathol Soc London. 1893;44:147-8.

5. Wainwright JM. Carcinoma of the male breast. Arch Surg. 1927;14:836-59.

6. Congdon GH, Dockerty MB. Malignant lesions of the nipple exclusive of Paget's disease. Surg Gynecol Obstet. 1956;103(2):185-92.
7. Farrow JH. Benign and malignant lesions of the nipple. CA Cancer J Clin. 1958;8(1):16-9.

8. Wyatt AP. Basal cell carcinoma of the male breast. Proc R Soc Med. 1965;58(7):509-10.

9. Lupton GP, Goette K. Basal cell carcinoma of the nipple. Arch Dermatol. 1978;114(12):1845.

10. Rahbari H, Mehregan AH. Basal cell epitheliomas in usual and unusual sites. J Cutan Pathol. 1979;6(5):425-31.

11. Robins P, Rabinovitz HS, Rigel D. Basal-cell carcinomas on covered or unusual sites of the body. J Dermatol Surg Oncol. 1981;7(10):803-6.

12. Knudsen PJ. Basel cell carcinoma of the nipple. Ugeskr Laeger. 1982;144(12):876-7.

13. Bruce S, Tschen JA, Goldberg LH. Basal-cell carcinoma of the nipple. J Dermatol Surg Oncol. 1985;11(4):424-5.

14. Nirodi NS, Mudd DG. Basal cell carcinoma of the male nipple. J R Coll Surg Edinb. 1986;31(2):121-3.

15. Cain RJ, Sau P, Benson PM. Basal cell carcinoma of the nipple. Report of two cases. J Am Acad Dermatol. 1990;22(2 Pt 1):207-10.

16. Titzmann T, Peter RU, Thoma E, Ruzicka T. Pigmented basalioma as pseudomelanoma of the breast. Hautarzt. 1991;42(7):459-60.

17. Benharroch D, Geffen DB, Peiser J, Rosenberg L. Basal cell carcinoma of the male nipple. Case report and review of the literature. J Dermatol Surg Oncol. 1993;19(2):137-9.

18. Weber PJ, Moody BR, Foster JA. Series spiral advancement flap: an alternative to the ellipse. Dermatol Surg. 2001;27(1):64-6.

19. Betti R, Martino P, Moneghini L, Vergani R, Tolomio E, Crosti C. Basal cell carcinomas of the areola-nipple complex: case reports and review of the literature. J Dermatol. 2003;30(11):822-6.

20. Gupta C, Sheth D, Snower DP. Primary basal cell carcinoma of the nipple. Arch Pathol Lab Med. 2004;128(7):792-3.

21. Nouri K, Ballard CJ, Bouzari N, Saghari S. Basal cell carcinoma of the areola in a man. J Drugs Dermatol. 2005;4(3):352-4.

22. Kim JH, Oh JW, Shin DH, Kim SI, Park BW. Basal cell carcinoma of the nipple-areolar complex J Korean Surg Soc. 2007;72:143-6. 
23. Avci O, Pabuccuoglu U, Kocdor MA, Unlu M, Akin C, Soyal C, Canda T. Basal cell carcinoma of the nipple-an unusual location in a male patient. J Dtsch Dermatol Ges. 2008;6(2):130-2.

24. Cummins DL, Yu Y, Finn DT. Island pedicle reconstruction of partial nipple and areola defect. Dermatol Surg. 2010;36(9):1459-62.

25. Oram Y, Demirkesen C, Akkaya AD, Koyuncu E. Basal cell carcinoma of the nipple: an uncommon but ever-increasing location. Case Rep Dermatol Med. 2011;2011:818291.

26. Kacerovska D, Michal M, Kazakov DV. Basal cell carcinoma of the nipple extending into the lactiferous duct. Int J Surg Pathol. 2011;19(6):779-80.

27. Sinha A, Langtry JA. Secondary intention healing following Mohs micrographic surgery for basal cell carcinoma of the nipple and areola. Acta Derm Venereol. 2011;91(1):78-9.

28. Williams C, Hussain W. A low-risk tumour, at a high-risk site? Basal cell carcinoma of the nipple-areola complex. $\mathrm{Br} \mathrm{J}$ Dermatol. 2013;168(4):901-3.

29. Brown PJ, Milch JM, Hivnor CM. Pigmented basal cell carcinoma of the nipple: a case report and review of the literature. Cutis. 2013;92(5):253-7.

30. Kalyani R, Vani BR, Srinivas MV, Veda P. Pigmented Basal cell carcinoma of nipple and areola in a male breast-a case report with review of literature. Int J Biomed Sci. 2014;10(1):69-72.

31. Takeno S, Kikuchi N, Miura T, Anami K, Takahashi Y, Hashimoto T, Moroga T, Akizuki S, Kamei M, Suehiro S, Yamashita S, Kawahara K. Basal cell carcinoma of the nipple in male patients with gastric cancer recurrence: report of a case. Breast Cancer. 2014;21(1):102-7.

32. Miglino B, Tiberio R, Astolfi S, Graziola F, Boggio P, Leutner M, Valente G, Franchini R, Colombo E. Basal cell carcinoma of the nipple in a male patient: a particular case report. Breast J. 2016;22(3):339-41.

33. Kitamura S, Hata H, Yamaguchi $Y$, Imafuku K, Yanagi T, Shimizu H. The Unique Dermoscopic Structure 'Large black web' in basal cell carcinoma on the areola. J Eur Acad Dermatol Venereol. 2016. doi:10.1111/jdv.13552.

34. Davis AB, Patchefsky AS. Basal cell carcinoma of the nipple: case report and review of the literature. Cancer. 1977;40(4):1780-1.

35. Jones R, Wayte DM, Mitchell E, Beer WE. Basal-cell carcinoma of the breast-treatment with retinoids. Clin Exp Dermatol. 1991;16(6):448-50.
36. Betti R, Urbani CE, Lodi A, Crosti C. Unusual sites of basal cell epitheliomas according to anatomical distribution and relative tumor density index. Eur J Dermatol. 1992;2:82-4.

37. Wong SW, Smith JG Jr, Thomas WO. Bilateral basal cell carcinoma of the breasts. J Am Acad Dermatol. 1993;28(5 Pt 1):777.

38. Nunez M, Marques A, de las Heras ME, Miralles ES, Ledo A. Bilateral basal cell carcinoma of the breasts in a woman. J Dermatol. 1995;22(3):226-8.

39. Sauven P, Roberts A. Basal cell carcinoma of the nipple. J R Soc Med. 1983;76(8):699-701.

40. Sanchez-Carpintero I, Redondo P, Solano T. Basal cell carcinoma affecting the areola-nipple complex. Plast Reconstr Surg. 2000;105(4):1573.

41. Yamamoto H, Ito $\mathrm{Y}$, Hayashi $\mathrm{T}$, Urano N, Kato T, Kimura Y, Tanigawa T, Endo W, Kurokawa E, Kikkawa N, Taniguchi $\mathrm{H}$. A case of basal cell carcinoma of the nipple and areola with intraductal spread. Breast Cancer. 2001;8(3):229-33.

42. Zhu YI, Ratner D. Basal cell carcinoma of the nipple: a case report and review of the literature. Dermatol Surg. 2001;27(11):971-4.

43. Huang CW, Pan CK, Shih TF, Tsai CC, Juan CC, Ker CG. Basal cell carcinoma of the nipple-areola complex: a case report. Kaohsiung J Med Sci. 2005;21(10):480-3.

44. Rosen N, Muhn CY, Bernstein SC. A common tumor, an uncommon location: basal cell carcinoma of the nipple and areola in a 49-year-old woman. Dermatol Surg. 2005;31(4):480-3.

45. Chu PY, Teng TH, Lee CC. Primary superficial basal cell carcinoma of the nipple. Ann Saudi Med. 2007;27(4):296-7.

46. Jung HJ, Jun JH, Kim HY, Lee SJ, Kim do W, Lee WJ, Jung JH. Pigmented Basal cell carcinoma of the nipple-areola complex in an elderly woman. Ann Dermatol. 2011;23(Suppl 2):S201-4.

47. Sharma A, Tambat RM, Singh A, Bhaligi DS. Basal cell carcinoma of the nipple areola complex. J Midlife Health. 2011;2(2):89-90.

48. Xu D, Tian W, Li J, Song Y. The missing nipple: a rare case of Basal cell carcinoma of the nipple in a Chinese female. Breast J. 2012;18(6):606-7.

49. Trignano E, Manzo MJ, Paliogiannis P, Madonia M, Marongiu F, Lissia A, Campus GV. Basal cell carcinoma of the nipple-areola complex: report of 
a case and literature review. Ann Ital Chir. 2013;84 (ePub).

50. Goddard L, Mollet T, Blalock T. Resident rounds part III: plaque on left areola of an African-American woman. J Drugs Dermatol. 2014;13(6):767

51. Ozerdem U, Hoda SA. Basal cell carcinoma of the nipple. Breast J. 2014;20(4):427-9.

52. Alessi E, Venegoni L, Fanoni D, Berti E. Cytokeratin profile in basal cell carcinoma. Am J Dermatopathol. 2008;30(3):249-55.

53. Pinkus H. Premalignant fibroepithelial tumors of skin. AMA Arch Derm Syphilol. 1953;67(6):598-615.

54. Wallace SA, Halpert B. Trichoma: tumor of hair anlage. Arch Pathol (Chic). 1950;50(2):199-208.

55. Ferguson MS, Nouraei SA, Davies BJ, McLean NR. Basal cell carcinoma of the nipple-areola complex. Dermatol Surg. 2009;35(11):1771-5.

56. Rogers HW, Weinstock MA, Harris AR, Hinckley MR, Feldman SR, Fleischer AB, Coldiron BM.
Incidence estimate of nonmelanoma skin cancer in the United States, 2006. Arch Dermatol. 2010;146(3):283-7.

57. Requena L, Sangueza M, Sangueza OP, Kutzner H. Pigmented mammary Paget disease and pigmented epidermotropic metastases from breast carcinoma. Am J Dermatopathol. 2002;24(3):189-98.

58. Xiong YD, Ma S, Li X, Zhong X, Duan C, Chen Q. A meta-analysis of reflectance confocal microscopy for the diagnosis of malignant skin tumours. J Eur Acad Dermatol Venereol. 2016. doi:10.1111/jdv. 13712.

59. Gonzalez S, Tannous Z. Real-time, in vivo confocal reflectance microscopy of basal cell carcinoma. J Am Acad Dermatol. 2002;47(6):869-74.

60. Menzies SW. Dermoscopy of pigmented basal cell carcinoma. Clin Dermatol. 2002;20(3):268-9.

61. di Meo N, Damiani G, Vichi S, Fadel M, Nan K, Noal C, Trevisini S, Trevisan G. Interobserver agreement on dermoscopic features of small basal cell carcinoma $(<5 \mathrm{~mm})$ among low-experience dermoscopists. J Dermatol. 2016. doi:10.1111/ 1346-8138.13426. 